\title{
ORIGINAL
}

\section{Photodegradation of Surfactants. III.}

\section{Heterogeneous Photocatalytic Degradation of Cationic Surfactants on $\mathrm{TiO}_{2}$ Particles}

\author{
Hisao HidAKA*a), Yasuji FujitA*, Kazuya IHARA*, Shinya YAmadA*, \\ Keiichi SuZUKI*, Nick SeRPONE**, and Ezio PELIZZETti*** \\ * Department of Chemistry, Meisei University \\ (2-1-1, Hodokubo, Hino-shi, Tokyo T191) \\ ** Department of Chemistry, Concordia University \\ (1455 de Maisonneuve Blvd., West Montreal, Quebec H3G 1 M 8, Canada) \\ *** Dipartimento di Chimica Analitica, Universita di Torino, \\ (5, Via Pietro Giuria, Torino 10125, Italy)
}

\begin{abstract}
The heterogeneous photocatalytic degradation of cationic surfactants including benzyldodecyle dimethyl ammonium chloride (BDDAC) was carried out in the presence of oxygen with powdery $\mathrm{TiO}_{2}$ suspended. The surface activity was lowered with irradiation time. The long alkyl chain and aromatic moiety in BDDAC were competitively degraded.

The photocatalytic decomposition rate of BDDAC was faster in a neutral than an acidic or alkaline medium.
\end{abstract}

\section{Introduction}

Chlorine-containing organic chemicals cause serious environmental problems owing to their toxicity and widespread utilization. Since these chemicals are not biodegradable, a photo= catalytic process may provide an effective means for their decomposition.

Photodecomposition of haloaromatics such as chlorobenzene $^{1) \sim 3)}$, chlorophenol ${ }^{4), 5)}$, and poly= chlorinated biphenyl $(\mathrm{PCB})^{6)}$ has been already reported. Further, halogenated organic sol= vents such as trichloroethylene, dichloroethane, and chloroform, which are widely used in the fields of advanced technology (e.g. IC fabricas tion), were photodegrated to non-toxic $\mathrm{CO}_{2}$ and $\mathrm{HCl}$ by heterogeneous photocatalytic ox= idation ${ }^{77,8)}$. Concerning surfactants which are predominant wastewater contaminants, to our knowledge there has been no research except on the photodegradation of sodium dodecyl= benzene sulfonate ${ }^{9) \sim 11)}$. Cationic surfactants of common use undergo slow biodegradation be= cause of their bactericidal activity, and they are more toxic to animals and plants than

a) To whom correspondence should be addressed. other kinds of surfactants ${ }^{12), 13)}$. In ecological points of view, a complete wastewater treatment is urgently required.

This paper describes effective decomposition of cationic surfactants by semiconductor photo $=$ catalysis.

\section{Experimental}

Reagent-grade benzyldodecyldimethylammo= nium chloride[BDDAC; $\mathrm{CH}_{3}\left(\mathrm{CH}_{2}\right)_{11} \mathrm{~N}^{+}\left(\mathrm{CH}_{3}\right)_{2}=$ $\mathrm{CH}_{2} \mathrm{C}_{6} \mathrm{H}_{5} \mathrm{Cl}^{-}$], benzyltrimethylammonium chlo= ride [BTAC; $\mathrm{C}_{6} \mathrm{H}_{5} \mathrm{CH}_{2} \mathrm{~N}^{+}\left(\mathrm{CH}_{3}\right)_{3} \mathrm{Cl}^{-}$], and hexas decyltrimethylammonium bromide [HDTAB; $\left.\mathrm{C}_{16} \mathrm{H}_{33} \mathrm{~N}^{+}\left(\mathrm{CH}_{3}\right)_{3} \mathrm{Br}^{-}\right]$, were used as supplied from Wako Pure Chem. Ind., Ltd.

Deionized water was used after distillation. As an $n$-type semiconductor photocatalyst, pow= dery $\mathrm{TiO}_{2}$ (Degussa P25, mostly anatase, sur= face area $55 \mathrm{~m}^{2} \cdot \mathrm{g}^{-1}$ ) was employed. A $25-\mathrm{mL}$ aerated or oxygenated aqueous solution of BDDAC, BTAC, or HTAB (50 ppm) with $50 \mathrm{mg}$ of suspended $\mathrm{TiO}_{2}$ was irradiated with a 500-W xenon lamp (Ushio Inc.) in a Pyrex reaction vessel $(37 \mathrm{~mL})$ under magnetic stirr = ing at about $37^{\circ} \mathrm{C}$. After photolysis, the slurry was centrifuged with a Hitachi centrifuge 
(Model SCT-4BD) for at least $20 \mathrm{~min}$ and then filtered with a millipore SJGV 013 NS filter (pore size $0.22 \mu \mathrm{m}$ ), and the spectral changes were monitored with a JASCO spectrophoto= meter (Model UVIDEC-660).

The concentrations of BDDAC and BTAC were determined spectrophotometrically at ei= ther $208.0 \mathrm{~nm}$ or $262.4 \mathrm{~nm}$.

Major intermediates in the photodegradation were identified with a Hitachi NMR spectro= photometer (Model R-22, $90 \mathrm{MHz}$ ). In order to prevent the $\mathrm{pH}$ effect, a capillary containing a $\mathrm{D}_{2} \mathrm{O}$ solution of sodium 3-(trimethylsilyl)-1propanesulfonate (DSS) as a reference was placed in a sample tube. The $\mathrm{D}_{2} \mathrm{O}$ solution of BDDAC (2 wt $\%$ ) was adjusted to $\mathrm{pH} 10.0$ with $\mathrm{NaOD}$ (Merck) or to $\mathrm{pH} 4.0$ with $\mathrm{DCl}$ (Merck) with a micro $\mathrm{pH}$-electrode. The sur= face tension of the solutions, after removal of $\mathrm{TiO}_{2}$ particles by centrifuging $(>10 \mathrm{~min})$ fol $=$ lowed by filtration, was measured at ambient temperature by a Whilhelmy's vertical plate method with a Shimadzu tensiometer (Model ST-1).

\section{Results and Discussion}

Time courses for the surface tension of BDDAC solutions during photolysis are shown! in Fig. -1 as a function of BDDAC concentra $=$

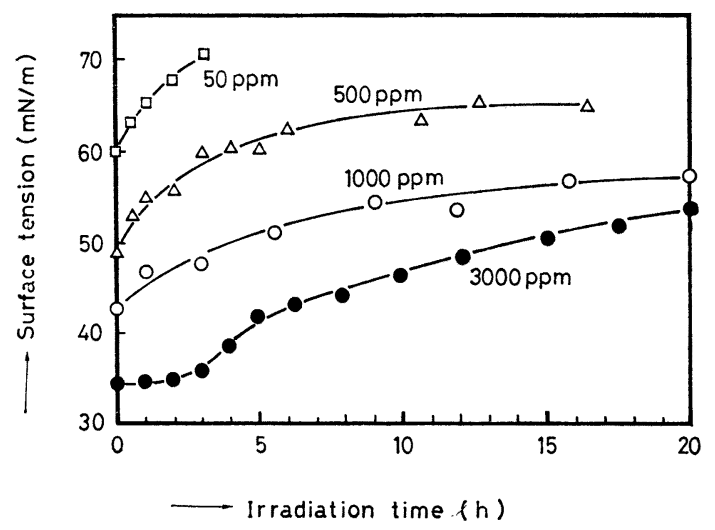

$: 50 \mathrm{ppm}(0.15 \mathrm{mM}), \triangle: 500 \mathrm{ppm}(1.51 \mathrm{mM})$ : $1000 \mathrm{ppm}(3.02 \mathrm{mM}),: 3000 \mathrm{ppm}(9.06 \mathrm{mM})$ cf. cmc. $7.74 \mathrm{mM}(2633 \mathrm{ppm})$ at $25^{\circ} \mathrm{C}$

Fig.-1 Temporal evolution of surface tension, reflecting photodegradation of BDDAC under xenon lamp illumination $(>330$ $\mathrm{nm})$. tion.

At a concentration of $50 \mathrm{ppm}$, which is well below the cmc, BDDAC was decomposed with= in $2 \mathrm{~h}$. At higher concentrations, the decoms position of BDDAC was slower. Above the $\mathrm{cmc}$, i.e. at $3000 \mathrm{ppm}$, the surface tension did not change until $3 \mathrm{~h}$ irradiation, and a longer irradiation time was required for complete degradation. The foam caused by stirring the BDDAC solution (50 ppm) during photolysis disappeared after $30 \mathrm{~min}$ irradiation.

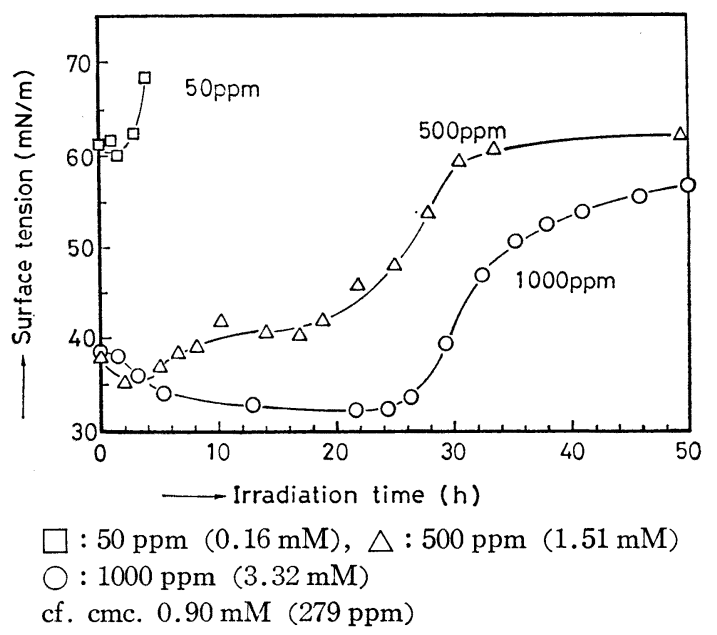

Fig.-2 Same as Fig.-1 but for HDTAB.

Table-1 pH Dependence of degradation half-life period*.

\begin{tabular}{c|c|c|c}
\hline & Initial pH & Final $\mathrm{pH}^{* *}$ & $\begin{array}{c}\text { Degradation } \\
\text { half-life } \\
t_{1 / 2}(\mathrm{~min})\end{array}$ \\
\hline \multirow{2}{*}{ BDDAC } & 1.6 & 1.8 & 180 \\
& 2.6 & 3.3 & 75 \\
& 4.0 & 4.0 & 50 \\
& 6.0 & 4.8 & 35 \\
& 6.8 & 5.4 & 25 \\
& 6.8 & 5.6 & 30 \\
& 7.0 & 5.2 & 25 \\
& 8.0 & 5.8 & 35 \\
& 10.2 & 6.3 & 50 \\
& 12.0 & 8.5 & 260 \\
& 3.6 & 4.2 & 30 \\
& 6.8 & 5.4 & 14 \\
& 10.4 & 6.3 & 17
\end{tabular}

* BDDAC or BTAC solutions (50ppm, $25 \mathrm{~mL}$ ) were photodegraded with $50 \mathrm{mg}$ of $\mathrm{TiO}_{2}$ by xenon lamp illumination $(>330 \mathrm{~nm})$.

** The $\mathrm{pH}$ value after $5 \mathrm{~h}$ irradiation. 
A similar plot for the photodegradation of HDTAB is illustrated in Fig.-2.

At $50 \mathrm{ppm}, \mathrm{HDTAB}$ was degraded in $4 \mathrm{~h}$ of irradiation. The degradation of HDTAB was very slow at concentrations above the $\mathrm{cmc}(279$ ppm). In contrast to BDDAC, HDTAB does not possess an aromatic moiety. The aromatic group hence appears to be a 'target' for photo= degradation.

The $\mathrm{pH}$ dependence of degradation half-life for the aromatic moiety of BDDAC and BTAC is given in Table-1.

The decomposition of BDDAC having a long alkyl chain is slower than that of BTAC. The decomposition half-life periods for both BDDAC and BTAC are shorter in neutral medium than in acidic and alkaline media. $\mathrm{TiO}_{2}$ has an amphoteric property with the iso= electric point (pI) of 5.3 , to which the $\mathrm{pH}$ value during photolysis gradually approaches.

Since the $\mathrm{TiO}_{2}$ surface in an acidic medium possesses positively charged $-\mathrm{OH}_{2}{ }^{+}$groups, the cationic BDDAC is repelled and therefore the decomposition is slowed. On the other hand, the $\mathrm{TiO}_{2}$ surface is negatively charged in an alkaline medium due to the presence of $-\mathrm{O}^{-}$. The BDDAC surfactant cations must be strongly adsorbed on the negative $\mathrm{TiO}_{2}$ surface by coulombic interaction. Hence the attack of more reactive $\mathrm{OH}$ radical, formed via the formation of electron-hole, to the aros matic group is lowered. Consequently, the catalytic action of $\mathrm{TiO}_{2}$ is weakened in an al= kaline medium.

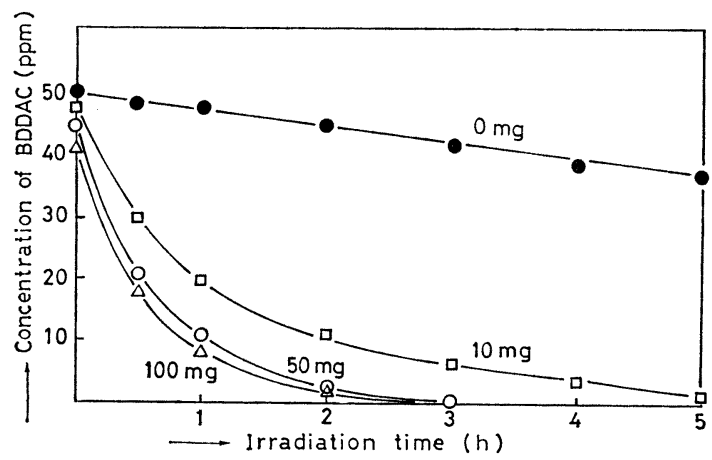

: in the absence of $\mathrm{TiO}_{2}, \square: 10 \mathrm{mg} \mathrm{TiO} / 25 \mathrm{~mL}$ $\bigcirc: 50 \mathrm{mg} \mathrm{TiO}_{2} / 25 \mathrm{~mL}, \triangle: 100 \mathrm{mg} \mathrm{TiO} / 25 \mathrm{~mL}$

Fig.-3 Effect of the amount of $\mathrm{TiO}_{2}$ catalysis on the photodegradation rate of BDDAC.

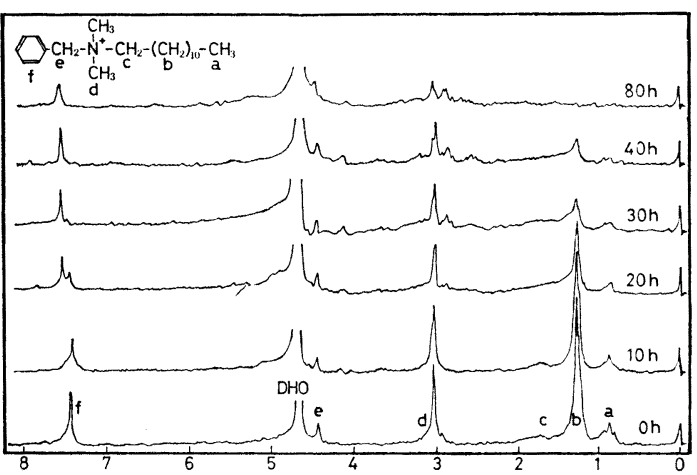

Fig.-4 NMR spectral evolution during BDDAC (2wt $\%$ ) photodegradation at $\mathrm{pH}=7.0$

The effect of the amount of $\mathrm{TiO}_{2}$ on the $\mathrm{BDDAC}$ degradation rate $(50 \mathrm{ppm}, 25 \mathrm{~mL})$ is shown in Fig.-3.

In the absence of the catalyst, BDDAC is slowly photodegraded and about $48 \mathrm{~h}$ irradia $=$ tion is required for attaining 95\% degradation. In fact, a further increase of the $\mathrm{TiO}_{2}$ content $(100 \mathrm{mg}$ or $200 \mathrm{mg}$ ) did not increase signifi= cantly the degradation rate. Light scattering by the turbid suspension may be one possible cause for this.

The presence of the catalyst and UV light is essential for rapid degradation of the sur= factants. Oxygen and water are also important ingredients for the photodegradation process, as confirmed by blank experiments.

The MMR spectra of $\operatorname{BDDAC}\left(2 \% \mathrm{D}_{2} \mathrm{O}\right.$ solution) for different irradiation times are il= lustrated in Fig-4.

In the initial stage, both the methylene peak (1. $25 \mathrm{ppm})$ and the aromatic peak (7.43 ppm) were gradually declined. A new peak (7.55 $\mathrm{ppm}$ ) assignable to the aromatic moiety arose accompanying photodegradation. This would reflect oxidation of the aromatic moiety to form hydroxy aromatics.

By further irradiation, the terminal methyl group $(0.87 \mathrm{ppm})$, and the dimethyl group adjacent to the ammonium cation (3.02 ppm) were slowly decomposed.

Consequently, the oxidation of benzene moiety and alkyl chain occurred competitively. Similar behaviors were noted in both alkaline and acidic media.

Although a detailed mechanism for photos decomposition cannot be deduced from the pre= 
sent data, we speculate, referring to the pub= lished results on the similar systems, the photo= oxidation mechanism as follows ${ }^{14) ~ 16)}$. Light absorption by $\mathrm{TiO}_{2}$ created electron/hole pairs. The holes are subsequently trapped by surface hydroxyl groups yielding adsorbed $\mathrm{OH}$ radi= cals. Alternatively, direct hole scavenging by the aromatic group in BDDAC adsorbed on the $\mathrm{TiO}_{2}$ surface could occur. These $\mathrm{OH}$ radi= cals, which are very reactive, attack the aros matic group to yield hydroxycyclohexadienyl radicals, and the radicals are further oxidized.

To summarize, cationic surfactants can be efficiently photodegraded in the presence of oxygen with $\mathrm{TiO}_{2}$ aqueous suspensions. The surface activity was lowered by ultraviolet ir= radiation. The long alkyl chain and the aros matic moiety in the surfactants were competi= tively decomposed.

\section{Acknowledgments}

The authors thank Mr. Y. Tamura for technical assistance and Dr. M. Moriya and Dr. M. Takai for their encouragement in this work. This work was supported in part by the Natural Science and Engi= neering Research Council of Canada and in part by the CNR of Italy.

(Received Feb. 13, 1987)

\section{References}

1) B.G. Oliver, E.G. Cosgove, and J.H. Carey, Environ. Sci. Technol., 13, 1075 (1979).

2) W. Matthews, Water Res., 20, 569 (1986).

3) R.W. Matthews, Sun World, 9, 3 (1985).

4) M. Barbeni, E. Pramauro, E. Pelizzetti, E. Borgarello, M. Gratzel, and N. Serpone, Nouv. J. Chem., 8, 547 (1984).

5) E. Pelizzetti, M. Barbeni, E. Pramauro, N. Serpone, E. Borgarello, M.A. Jamieson, and H. Hidaka, Chim. \& Ind. (Mirano), 67, 623 (1986).

6) J.H. Carey, J. Lawrence, and H.M. Toshine, Bull. Environ. Contam. Toxicol., 16, 697 (1976).
7) A.L. Pruden and D.F. Ollis, J. Catal., 82, 404 (1983).

8) C.Y. Hsiao, C.L. Lee, and D.F. Ollis, $J$. Catal., 82, 418 (1983).

9) H. Hidaka, H. Kubota, M. Gratzel, N. Ser= pone, and E. Pelizzetti, Nouv. J. Chim., 9, 69 (1985).

10) I. Izumi, Denki Kagaku, 53, 178 (1985).

11) H. Hidaka, H. Kubota, M. Gratzel, E. Peli= zzetti, and N. Serpone, J. Photochem., 35, 219 (1986).

12) S. Ito, S. Setsuda, A. Utsunomiya, and S. Naito, Yukagaku, 28, 199 (1979).

13) B.H. Fenger, M. Mandrup, G. Rohde, and J.C.K. S $\phi$ rensen, Water Research, 7, 1195 (1973).

14) M. Gratzel, Ed., "Energy Resources through Photochemistry and Catalysis", Academic Press, New York, 1983.

15) M. Fujihira, Y. Satoh, and T. Osa, Bull. Chem. Soc. Jpn., 55, 666 (1982).

16) R.W. Matthews, J. Chem. Soc., Faraday Trans. I, 80, 457 (1984).

\section{界面活性剂の光分解（第 3 報）}

酸化チタンを用いるカチオン界面 活性剂の不均一系光触媒的分解

日高久夫* ・藤田康治* ・井原和也* - 山田慎也* 鈴木恵一*・ニック セルポーン**

$$
\text { エジオ ペリツェティ** }
$$

* 明星大学理工学部化学科 (广191 日野市程久保 2-1-1)

** コンコーデア大学化学科

（ド・メゾヌーブ通り 1455 , ウェストモントリオール， ケベック, H 3 G, 1 M 8, カナダ)

*** トリノ大学分析化学部 (ピエトロジウリア通り 5 , トリ ( 10125, イタリア)

カチオン界面活性剤ベンジルドデシルジメチルアンモ ニウムニクロリド (BDDAC) を, 不均一系光触媒 $\mathrm{TiO}_{2}$ を用い, 酸素存在下で光分解した。表面張力が時間と共 に低下した。BDDAC の長鎖部分と芳香基部分が競争 的に分解した。中性領域の方が酸またはアルカリ領域よ り分解速度は速い。 